\title{
Association between apolipoprotein E polymorphisms and gastric cancer in a hospital-based Turkish population
}

\author{
Tuğcan Korak'1,*, Nihal Üren'1, Emel Ergül1', Turgay Șimșek², Ali Sazcı ${ }^{1}$, Nuh Zafer Cantürk², \\ Nihat Zafer Utkan² \\ ${ }^{1}$ Department of Medical Biology, School of Medicine Kocaeli University, 41000, Kocaeli, Turkey \\ ${ }^{2}$ Department of General Surgery, School of Medicine Kocaeli University, 41000, Kocaeli, Turkey
}

Cite this article as: Korak T, Üren N, Ergül E, Șimșek T, Sazcı A, Cantürk NZ, Utkan NZ (2017). Association between apolipoprotein E polymorphisms and gastric cancer in a hospital-based Turkish population. Istanbul J Pharm 47 (3): 97-100.

\section{ABSTRACT}

Apolipoprotein E (ApoE) is an important secretory glycoprotein, and also a ligand for LDL receptors and ApoE receptors. It is involved in lipid transport and catabolism, nerve regeneration, immune system regulation, and cell proliferation. Moreover, both the causative and protective effects of APOE polymorphic variants and alleles have been correlated with several diseases, including cancer types such as gastric cancer. However, to the best of our knowledge, no data are available describing the association between gastric cancer and $A P O E$ polymorphisms in the Turkish population. In this context, this study was conducted to evaluate the association between the genotypes of $A P O E$ and the risk of gastric cancer and also to demonstrate the allele frequencies and genotype distributions of $A P O E$ gene in a hospital-based Turkish population with gastric cancer. A total of 59 patients with gastric cancer and 200 healthy controls were included in this study. Results showed the absence of any statistically significant association between $A P O E$ gene polymorphisms and the risk of gastric cancer $\left(\chi^{2}=2.711, p=0.744\right)$, which could possibly be due to the small sample size of our study. Therefore, further investigations such as expression studies and meta-analysis comprising larger sample size and detailed demographic data are necessary to identify the alleles of APOE gene associated with the risk of gastric cancer.
\end{abstract}

Keywords: Gastric cancer, $A P O E$ polymorphisms, Turkish population

\section{INTRODUCTION}

Gastric cancer, also called stomach cancer, is the first cause of cancer-related mortality worldwide (Türkiye Halk Sağlığı Kurumu 2017). The incidence rate of gastric cancer is falling worldwide; however, still nearly 730,000 deaths are encountered per year (Parkin et al. 2001). Environmental and genetic factors play an important role in the development of gastric cancer. Helicobacter Pylori infection and infection related gastritis are the common environmental factors implicated in its causation, besides others such as diet, smoking, and geographical location (Sipponen 2002; Yaghoobi et al. 2010). However, genetic and familial contributors have not yet been extensively investigated in studies (Yaghoobi et al. 2010).

Recently, the attention has been focused on combined effect of low-penetrance alleles as a potential risk factor for causation of gastric cancer. In this respect, gastric cancer associated genes need to be further identified and expanded (Yaghoobi et al. 2010). Apolipoprotein E (APOE) is one of the genes (19q13.2) that is implicated in causation of gastric cancer (De Feo et al. 2012). The APOE gene is a high affinity ligand for low density lipoprotein (LDL) receptors and apoE receptors found in hepatic tissues and plays an important role in lipid transport and catabolism (Uniprot 2017; Sazci et al. 2008). The APOE gene consists of 3 introns and 4 exons, and due to two single nucleotide mutations in the coding region of APOE gene, three alleles $(\varepsilon 2, \varepsilon 3$, and $\varepsilon 4)$ and three homozygotes (apoE2/2, E3/3 and E4/4) and three heterozygotes (apoE2/3, E2/4, and E3/4) genotypes are formed (Sazci et al. 2008; De Feo et al. 2012). These isoforms are different in terms of amino acid constitution at positions 112 and 158 ; apoE2 (cys- 
teine112/cysteine158), apoE3 (cysteine112/arginine158) and apoE4 (arginine112/arginine158). These substitutions give rise to the difference in isoelectric points among isoforms, so that each differs by receptor binding capacity (Zannis et al. 1982; Sazci et al. 2008; De Feo et al. 2012). Based on these, APOE polymorphisms may affect plasma cholesterol and LDL concentrations or signaling pathways; thus, causing cancer. Studies on several populations have suggested that cholesterol and LDL levels differ from lowest to highest in people carrying $\varepsilon 2, \varepsilon 3$, and $\varepsilon 4$ alleles, respectively. Also, some studies have supported that genetic polymorphism is responsible for $60 \%$ of variations in levels of plasma cholesterol and APOE polymorphisms accounts for nearly 14\% of this ratio (Weisgraber 1990; Sakashita et al. 2008).

APOE gene $\varepsilon 3$ allele is reported as the common and neutral allele found in 40\%-90\% of the populations and correlated with prostate cancer and polycystic ovary syndrome (Cetinkalp et al. 2009; Uen et al. 2015; Yencilek et al. 2016; Uniprot 2017). APOE gene $\varepsilon 2$ allele was correlated with some other diseases such as type III hyperlipoproteinemia and Parkinson's disease. Nonetheless, it plays a protective role in gastric cancer (Cibeira et al. 2014; Uen et al. 2015). APOE gene $\varepsilon 4$ allele was correlated with Alzheimer's disease, coronary heart disease and several cancer types including prostate, breast, head and neck cancers (Uen et al. 2015). On the other hand, studies have shown that people with low total serum cholesterol levels are more prone to develop cancer. The mechanism regarding susceptibility to gastric cancer in this population is unclear; nevertheless, some of available estimations are low cholesterol levels, effects of different structural stabilities of apoE isoforms on tumor growth, variable interactions between apoE isoforms and their targets. Moreover, possible variability in post-translational modifications of plasma apoE may affect diseases or cancer development (De Feo et al. 2012; Uen et al. 2015).

Based on these data, we investigated association between genotypes of the APOE gene and gastric cancer risk in a hospital-based Turkish population in a case-control study including 59 gastric cancer patients and 200 healthy controls.

\section{MATERIALS AND METHODS}

\section{Study population}

This study consists of 59 gastric cancer patients and 200 healthy controls. The 59 gastric cancer patients were obtained from the Kocaeli University Hospital. Male and female ratios were matched in the cases and controls. The study was approved by the Ethic Committee of Kocaeli University (GOKAEK 2017/14.42).

\section{Genotyping}

Genomic DNA was isolated by using the conventional salting-out method (Miller et al. 1988). Genotyping was done by a PCR-RFLP method. In the PCR reaction 5'-ATGGACGAGACCATGAAGGAGTTGAAG-3' was used as forward and 5'-TGTACCAGGCCGGGGCCCGCGA-3' was used as reverse primer. The PCR conditions were as follows: $96^{\circ} \mathrm{C}$ for 2 min followed by 35 cycles at $96^{\circ} \mathrm{C}$ for $1 \mathrm{~min}, 67^{\circ} \mathrm{C}$ for $2 \mathrm{~min}, 72^{\circ} \mathrm{C}$ for $2 \mathrm{~min}$ and final extension step at $72^{\circ} \mathrm{C}$ for 4 min. The $314 \mathrm{bp}$ long PCR product was digested with $2 \mathrm{U}$ Hin6l enzyme and the digestion products were run in 10\% PAGE for 30 min at $20 \mathrm{~W}$. The corresponding fragments for ApoE genotypes were given in Table 1.

\section{Statistical Analysis}

Genotype frequencies between gastric cancer patients and controls were compared by $X 2$ test. The odds ratio (OR) and 95\% confidence intervals (Cl) were used to verify the effects of the genotypes and alleles. Statistical analysis were done by SPSS (version 21.0 IBM Corp.; Armonk, NY, USA) software package. $p$-value less than 0.05 was accepted as significant.

\section{RESULTS AND DISCUSSION}

Gastric cancer accounts for many cancer-related deaths. Some single nucleotide polymorphisms in the corresponding regions have been reported as a genetic risk factor on gastric cancer. Both genetic risk factor and protective effects of APOE polymorphic variants and alleles have been correlated with several disease and cancer types including gastric cancer. The current study including 59 gastric cancer patients and 200 controls revealed that there is no association between APOE genotypes and gastric cancer and this study is the first study in the Turkish population (Table 2).

Previous studies demonstrated the genotype distribution of APOE gene alleles on gastric cancer. When the genotype distribution of our study was compared with the study done in Italian population, E2/2 and E4/4 genotypes were not found in the cases for both population. Also, the frequencies of E2/3 and $E 3 / 4$ in both populations are in consistent in terms of their distribution among cases and controls. Moreover, E3/3 genotype was reported as the most common genotype in cases; $71.71 \%, 76.3 \%$ and controls; $62.94 \%, 70.0 \%$ for the Italian and Turkish population studied herein, respectively (De Feo et al. 2012). Similarly, E3/3 genotype was found as common, E2/2 is observed rarely and E3/4 genotype frequencies are close to each other in the study done in the Chinese Han population for both groups. In contrast to Italian and Turkish population, E2/3 genotype frequency is higher in gastric cancer patients than controls and higher frequencies for E4/4 and E2/4 were obtained in the cases of Chinese Han population. On the other hand, high frequency of APOE gene $\varepsilon 2$ allele and low serum total cholesterol are significantly correlated with gastric cancer in the Chinese Han population. Additionally, they proposed that higher risk of gastric cancer is due to the $\varepsilon 2$ allele and it could be related with reduced serum cholesterol levels (Kang et al. 2016). Conversely, ApoE $\varepsilon 2$ allele was reported as protective against gastric cancer in Italian population and the possible explanation of this phenomena was higher antioxidant properties of $\varepsilon 2$ allele than other alleles (De Feo et al. 2012). The differences of genotype distribution between Chinese population and other populations may be due to the different ethnicity, geographical location, environmental factors and lifestyle. Also, variations among studies performed in different populations might be attributed to the study population size. 
APOE gene polymorphic variants were studied in the Turkish population before, and they were correlated with various diseases such as type 2 diabetes (Erdogan et al. 2016), Alzheimer's disease (Acar Çinleti et al. 2015; Alaylıoğlu et al. 2016), coronary heart disease (Yılmaz-Aydogan et al. 2012), cerebrovascular disease (Tasdemir et al. 2008); however, there are only two studies regarding cancer that include breast (Yaylim et al. 2003) and prostate cancer (Yencilek et al. 2016). APOE gene polymorphic variants could affect the mechanism of cancer formation, thus it could be speculated that different cancer types might be associated with the same alleles in the same population. According to the study on breast cancer, no significant association was found between any alleles and breast cancer risk similar to some other studies and meta-analysis (Niemi et al. 2000; Yaylim et al. 2003; Liu et al. 2016). The distribution of E3/3 genotype is consistent with our results in terms of highest frequencies in both cases and controls, whereas the contrary results were obtained for $\varepsilon 4$ allele in which its frequency is $9.25 \%$ in controls for the present study and $0 \%$ for the study done on breast cancer (Yaylim et al. 2003). In the other study focusing on prostate cancer in a Turkish population, E3/3 genotype was found as a risk factor, while $\varepsilon 4$ allele was reported as protective (Yencilek et al. 2016). Even though some similarity was observed for different cancer types in the Turkish population, the obtained results have not high percentage consistency yet. The variability in results might be due to the small population size in ad-

\section{Table 1. The fragments of $A P O E$ genotypes}

\begin{tabular}{|ll}
\hline Genotypes & Fragments \\
\hline E2/2 & 109bp, 91bp, 79bp, 18bp, 16bp \\
E2/3 & 109bp, 91bp, 79bp, 48bp, 31bp, 18bp, 16bp \\
E2/4 & 109bp, 91bp, 79bp, 72bp, 48bp, 31bp, 19bp, 18bp, $16 \mathrm{bp}$ \\
E3/3 & 109bp, 91bp, 48bp, 31bp, 18bp, 16bp \\
E3/4 & 109bp, 91bp, 72bp, 48bp, 31bp, 19bp, 18bp, 16bp \\
E4/4 & 109bp, 72bp, 48bp, 31bp, 19bp, 18bp, 16bp \\
\hline
\end{tabular}

dition to different demographic properties of the populations studied. Based on these data, it was not possible to speculate which alleles attribute as a risk factor or which one is protective against cancer. This leads to the idea that there might be other factors that contribute to the development of various cancer types.

In the literature, there are few expression studies focused on APOE gene allelic variants and gastric cancer association. As mentioned briefly before, ApoE protein is a secretory glycoprotein that is a ligand for some receptors and it stimulates different signalling pathways. Apart from regulating lipid metabolism, it is involved in nerve regeneration, immune system regulation, cell proliferation. Moreover, it is correlated with several cancer types. One study aimed to show function of ApoE in stimulation of lymph node metastasis in gastric cancer. Overexpression of ApoE mRNA and dominant expression of ApoE protein products were detected in gastric cancer. Besides, deeper tumor invasion and more lymph node metastasis were observed in the cases having high ApoE expression. Based on these, it has been indicated that ApoE might cause gastric cancer through stimulation of signalling pathways resulting in tumor growth after binding to the LDL receptors (Sakashita et al. 2008). Another study focused on the APOE-associated genes and transcription factors in gastric cancer development. The responsible genes have function in JAK-STAT cascade, acute inflammatory response, steroid hormone response and acute phase response. Thus effective pathways causing gastric cancer have been determined (Shi et al. 2015).

In addition to the abovementioned mechanisms of APOE gene on cancer susceptibility, expression studies also provide some clues for focusing on the role of expression levels of APOE gene. Moreover, meta-analysis with large population size and comprehensive demographic data could confirm the causative alleles of $A P O E$ gene in gastric cancer. Our study contributes for revealing the genotype and allelic distribution of $A P O E$ gene in the Turkish population and may provide a basis for further studies in this field.

Table 2. Genotype and allele frequencies of $A P O E$ gene in gastric cancer patients and controls

\begin{tabular}{|c|c|c|c|c|c|}
\hline Genotypes & Gastric Cancer Patients, n (\%) & Controls, $\mathrm{n}(\%)$ & $\chi^{2}$ & $\mathrm{p}$ & $\mathrm{OR} ; 95 \% \mathrm{Cl}$ \\
\hline$A P O E$ & 59 (100.0) & $200(100.0)$ & 2.711 & 0.744 & \\
\hline $\mathrm{E} 2 / 2$ & $0(0.0)$ & $1(0.5)$ & 0.296 & 1.000 & $0.995(0.985-1.005)$ \\
\hline $\mathrm{E} 2 / 3$ & $6(10.2)$ & $23(11.5)$ & 0.081 & 0.960 & $0.871(0.337-2.251)$ \\
\hline E2/4 & $0(0.0)$ & $6(3.0)$ & 1.812 & 0.342 & $0.97010 .947-0.994$ \\
\hline $\mathrm{E} 3 / 3$ & 45 (76.3) & $140(70.0)$ & 0.878 & 0.440 & $1.378(0.704-2.697)$ \\
\hline $\mathrm{E} 3 / 4$ & $8(13.6)$ & $29(14.5)$ & 0.033 & 1.000 & $0.925(0.398-2.149)$ \\
\hline$E 4 / 4$ & $0(0.0)$ & $1(0.5)$ & 0.296 & 1.000 & $0.995(0.985-1.005)$ \\
\hline \multicolumn{6}{|l|}{ Alleles } \\
\hline$\varepsilon 2$ & $6(5.00)$ & $31(7.75)$ & 0.888 & 0.466 & $0.642(0.253-1.625)$ \\
\hline$\varepsilon 3$ & $104(88.14)$ & 332 (83.0) & 2.435 & 0.205 & $0.96010 .933-0.988$ \\
\hline$\varepsilon 4$ & $8(6.78)$ & 37 (9.25) & 0.637 & 0.548 & $0.715(0.312-1.636$ \\
\hline
\end{tabular}




\section{REFERENCES}

- Acar Çinleti B, Yardimci N, Aytürk Z, Ilhan A, Kaya G, Acar M, Koç ER, Gündüz E, Gündüz M (2015). The effects and interactions of APOE and $\mathrm{APH}-1 \mathrm{~A}$ polymorphisms in Alzheimer disease. Turk J Med Sci 45: 1098-1105. [CrossRef]

- Alaylığlu M, Gezen-Ak D, Dursun E, Bilgiç B, Hanağası H, Ertan T, Gürvit H, Emre M, Eker E, Uysal Ö, Yılmazer S (2016). The Association Between Clusterin and APOE Polymorphisms and LateOnset Alzheimer Disease in a Turkish Cohort. J Geriatr Psychiatry Neuro/ 29: 221-226. [CrossRef]

- Cetinkalp S, Karadeniz M, Erdogan M, Zengi A, Cetintas V, Tetik A, Eroglu Z, Kosova B, Ozgen AG, Saygili F, Yilmaz C (2009). Apolipoprotein $\mathrm{E}$ gene polymorphism and polycystic ovary syndrome patients in Western Anatolia, Turkey. J Assist Reprod Genet 26: 1-6. [CrossRef]

- $\quad$ Cibeira GH, Giacomazzi J, Aguiar E, Schneider S, Ettrich B, DE Souza Cl, Camey S, Caleffi M, Weber B, Ashton-Prolla P, Moriguchi EH (2014). Apolipoprotein E genetic polymorphism, serum lipoprotein levels and breast cancer risk: A case-control study. Mol Clin Oncol 2: 1009-1015. [CrossRef]

- De Feo E, Simone B, Persiani R, Cananzi F, Biondi A, Arzani D, Amore R, D'Ugo D, Ricciardi G, Boccia S (2012). A case-control study on the effect of Apolipoprotein E genotypes on gastric cancer risk and progression. BMC Cancer 12: 494. [CrossRef]

- $\quad$ Erdogan M, Eroglu Z, Kulaksizoglu M, Soner S, Tetik A, Cetinkalp $S$ (2016). The relationship of the apolipoprotein E gene polymorphism in Turkish Type 2 Diabetic Patients with and without diabetic foot ulcers. Diabetes Metab Syndr 10: S30-33. [CrossRef]

- $\quad$ Kang R, Li P, Wang T, Li X, Wei Z, Zhang Z, Zhong L, Cao L, Heckman MG, Zhang YW, Xu H, Huang C, Bu G, Chen XF (2016). Apolipoprotein $\mathrm{E}$ epsilon 2 allele and low serum cholesterol as risk factors for gastric cancer in a Chinese Han population. Sci Rep 28: 19930. [CrossRef]

- Liu YL, Zhang HM, Pan HM, Bao YH, Xue J, Wang TC, Dong XC, $\mathrm{Li} X \mathrm{~L}$, Bao HG (2016). The relationship between apolipoprotein $\mathrm{E}$ gene $\varepsilon 2 / \varepsilon 3 / \varepsilon 4$ polymorphism and breast cancer risk: a systematic review and meta-analysis. Onco Targets Ther 9: 1241-1249. [CrossRef]

- Miller SA, Dykes DD, Polesky HF (1988). A simple salting out procedure for extractingDNA from human nucleated cells. Nucleic Acids Res 16: 1215. [CrossRef]

- Niemi M, Kervinen K, Kiviniemi H, Lukkarinen O, Kyllo"nen A-P, Sarkkinen MA, Savolainen MJ, KairaluomaMI, Kesaniemi YA (2000). Apolipoprotein E phenotype, cholesterol and breast and prostate cancer. J Epidemiol Commun Health 54: 938-939. [CrossRef]

- Parkin DM, Bray Fl, Devesa SS (2001). Cancer burden in the year 2000. The global picture. Eur J Cancer Supp/ 8: S4-66. [CrossRef]
- Sakashita K, Tanaka F, Zhang X, Mimori K, Kamohara Y, Inoue H, Sawada T, Hirakawa K, Mori M (2008). Clinical significance of ApoE expression in human gastric cancer. Oncol Rep 20: 1313-1319.

- Sazci A, Akpinar G, Aygun C, Ergul E, Senturk O, Hulagu S (2008). Association ofapolipoprotein E polymorphisms in patients with non-alcoholic steatohepatitis. Dig Dis Sci 53: 32183224. [CrossRef]

- $\quad$ Shi X, Xu J, Wang J, Cui M, Gao Y, Niu H, Jin H (2015). Expression analysis of apolipoprotein $E$ and its associated genes in gastric cancer. Oncology Letters 10: 1309-1314. [CrossRef]

- $\quad$ Sipponen P (2002). Gastric cancer: pathogenesis, risks, and prevention. J Gastroentero/ Supp/ 13: 39-44. [CrossRef]

- Tasdemir N, Tamam Y, Toprak R, Tamam B, Tasdemir MS (2008). Association of apolipoprotein E genotype and cerebrovascular disease risk factors in a Turkish population. Int J Neurosci 118 1109-1129. [CrossRef]

- Uen YH, Liao CC, Lin JC, Pan YH, Liu YC, Chen YC, Chen WJ, Tai CC, Lee KW, Liu YR, Lin HT, Lin CY (2015). Analysis of differentially expressed novel post-translational modifications of plasma apolipoprotein E in Taiwanese females with breast cancer. J Proteomics 3; 252-262. [CrossRef]

- Weisgraber KH (1990). Apolipoprotein E distribution among human plasma lipoproteins: role of the cysteine-arginine interchange at residue 112. J Lipid Res. 31: 1503-1511.

- Yaghoobi M, Bijarchi R, Narod SA (2010). Family history and the risk of gastric cancer. Br J Cancer 102: 237-242. [CrossRef]

- Yaylim I, Bozkurt N, Yilmaz H, Isbir T, Isik N, Arikan S (2003). The apolipoprotein E $\varepsilon 4$ allele is not a risk factor for Turkish breast cancer patients. Cancer Genetics and Cytogenetics 146: 86-87. [CrossRef]

- Yencilek F, Yilmaz SG, Yildirim A, Gormus U, Altinkilic EM, Dalan AB, Bastug Y, Turkmen S, Turkan S, Isbir T (2016). Apolipoprotein E Genotypes in Patients with Prostate Cancer. Anticancer Res. 36 : 707-711.

- Yllmaz-Aydogan H, Kucukhuseyin O, Kurnaz O, Akadam-Teker B, Kurt O, Tekeli A, Ozturk O, Isbir T (2012). Investigation of polymorphic variants of PPARD and APOE genes in Turkish coronary heart disease patients. DNA Cell Bio/ 31: 867-875. [CrossRef]

Zannis VI, Breslow JL, Utermann G, Mahley RW, Weisgraber KH, Havel RJ, Goldstein JL, Brown MS, Schonfeld G, Hazzard WR, Blum C (1982). Proposed nomenclature of apoE isoproteins, apoE genotypes, and phenotypes. J Lipid Res 23: 911-914.

(2017) Türkiye Halk Sağlığı Kurumu, Kanser Daire Başkanlığı. Mide Kanseri, http://kanser.gov.tr/kanser/kanser-turleri/223-mide-kanseri.html. Accessed 18.10.2017.

(2017) Uniprot. UniProtKB - P02649 (APOE_HUMAN), http://www. uniprot.org/uniprot/P02649. Accessed 18.10.2017. 